\title{
Use of insulin in diabetes: a century of treatment
}

\author{
Savita Shahani * Lokesh Shahani
}

\section{A B S T R A C T}

Insulin is a key player in the control of hyperglycaemia for patients with type 1 diabetes mellitus and selected patients with type 2 diabetes mellitus. There have been many advances in insulin drug delivery from its first administration as a crude pancreatic extract till today. The traditional and most predictable method for administration of insulin is by subcutaneous injection. Currently available insulin delivery systems include insulin syringes, infusion pumps, jet injectors, and pens. The major drawback of insulin therapy is its invasive nature. Non-invasive delivery of insulin has long been a major goal for the treatment of diabetes mellitus. Although there have been improvements in insulin therapy since

This article was published on 6 Nov 2015 at www.hkmj.org. it was first conceived, it is still far from mimicking the physiological secretion of pancreatic $\beta$-cells, and research to find new insulin formulations and new routes of administration continues. This article reviews the emerging technologies, including insulin inhalers, insulin buccal spray, insulin pill, islet cell transplant, and stem cell therapy, as treatment options for diabetes mellitus.

\section{Hong Kong Med J 2015;21:553-9 DOI: $10.12809 / \mathrm{hkmj} 154557$ \\ ${ }^{1}$ S Shahani *, MD \\ ${ }^{2}$ L Shahani, MD \\ Department of Pharmacology, MGM Medical College Mumbai (India), India \\ 2 Department of Internal Medicine, Baylor College of Medicine, Houston, Texas, United States \\ * Corresponding author: drshahani@rediffmail.com}

\section{Introduction}

Diabetes mellitus is a major public health concern worldwide. There is predicted to be an alarming increase in the population with type 2 diabetes mellitus both in developed and developing countries over the next two decades. The prevalence of diabetes among adults aged 20 to 70 years is expected to rise from 285 million in 2010 to 438 million by the year 2030. ${ }^{1}$ Prevalences of diabetes and impaired glucose tolerance are high in all Asian countries and are expected to increase further in the next 20 years. The present trend indicates that more than $60 \%$ of the world's diabetic population will be in Asia. ${ }^{2}$ The prevalence of type 2 diabetes is particularly high in Asian Indians because of high genetic susceptibility and enhanced interaction with environmental triggers. Exposure to a high fat diet and low levels of physical activity are factors that can trigger the gene-environment interaction. ${ }^{2}$ Therapy with insulin is effective at lowering blood glucose in patients with diabetes. Insulin is a key treatment in the control of type 1 diabetes and it is required in the later stages by patients with type 2 diabetes mellitus; hyperglycaemia in type 1 diabetes is a result of insulin deficiency and, in type 2 diabetes, it is due to both impaired tissue response to insulin and insulin deficiency. The discovery of insulin has been hailed as one of the most dramatic events in the history of the treatment of diabetes.

Before the discovery of insulin, diabetes was a feared disease that led to death. Correlation of destruction of the pancreas with diabetes was observed in 1890 by von Mering and Minkowski, ${ }^{3}$ but internal secretion from the pancreas being responsible for control of sugar was not identified. In fact, the name 'insulin' was derived from the Latin word 'insula' (meaning 'island') much earlier than insulin was isolated.

As described by Bliss, ${ }^{4}$ between 1914 and 1916, Paulesco and Zuelzer performed studies on dogs with experimentally induced diabetes, showing the antidiabetic effect of extract from the pancreas, but they had to give up their experiments due to lack of funds and the publication of their work was delayed until July 1921. In 1922, Banting and Best ${ }^{5}$ confirmed the antidiabetic effect of pancreatic extract in dogs with experimentally induced diabetes. To carry on with the experiments in a larger number of animals, a substantial quantity of insulin was needed so pancreatic extract from cows started being used. The timeline of insulin development is shown in the Table. ${ }^{6-13}$

\section{Alternative devices}

At this stage (1984), insulin was only available in vials and needed to be administered subcutaneously via a syringe and needle, making it possible to mix different types of insulin preparations. Patients, however, found it inconvenient to administer and there were mistakes in dosage measurement. Therefore, alternative devices were developed to improve drug delivery of insulin. 


\section{使用胰島素治療糖尿病：近一個世紀的發展歷程}

\author{
Savita Shahani, Lokesh Shahani
}

胰島素是控制一型糖尿病患者和部分二型糖尿病患者血糖水平的關 鍵。胰島素從第一代粗胰腺提取液開始直至現在, 其服用途徑經過多 年的演變。傳統的胰島素導入方式是透過皮下注射。目前市面上的有 胰島素注射針、輸液永、無針式注射器和筆針。事實上, 胰島素療法 的主要缺點是其入侵性。一直以來, 非入侵性導入胰島素是糖尿病治 療的一個主要目標。胰島素治療方式雖然有所改善, 但仍遠遠不能模 擬胰島 $\beta$ 細胞的內分泌功能。正因如此, 現今仍不斷繼續尋找新的胰 島素製劑和導入方式。本文綜述糖尿病治療方案的新興技術, 包括經 鼻吸入的胰島素噴霧劑、經口腔黏膜吸收的胰島素噴劑、口服胰島素 藥片、胰島細胞移植和幹細胞療法。

\section{Insulin pen}

The insulin pen combines an insulin container and syringe in a single modular unit that makes it convenient to administer insulin because of the ease of insulin cartridge replacement. The insulin pen has an inbuilt dial system that allows administration of an accurate amount of drug. Pens are available as a single premixed insulin administration unit. ${ }^{14}$

\section{Insulin jet injector}

The insulin jet injector has been designed to deliver a fine spray of insulin subcutaneously at high speed using a pressurised jet of air instead of a needle. The dose is controlled by the dial-a-dose operation through a single component design in comparison to a conventional multi-component syringe. However the jet injector may cause bruising of the skin as well as having altered absorption levels. The size and cost of the jet injector further limit its routine use. This device can be considered for patients with needle phobia or those with severe insulin-induced lipoatrophy. ${ }^{15}$

\section{Injection port}

The injection port is another device that functions as a delivery channel directly into subcutaneous tissue. The injection port contains an insertion needle guiding a soft cannula into subcutaneous tissue. Once applied, the insertion needle is removed and a soft cannula remains in the subcutaneous tissue, acting as gateway through which insulin can be administered via a syringe or pen, thus avoiding multiple pricks. The injection port can be changed every third day. The device is available from Medtronic (Dublin, Ireland). ${ }^{16}$

\section{External insulin pump}

The external insulin pump is a small battery-operated device that is made up of an insulin reservoir connected to a tube ending in a cannula that is inserted under the skin of the abdomen and set to deliver continuous subcutaneous insulin infusion (CSII) throughout the day, and is programmed to deliver insulin in a larger quantity at meal times. This release pattern simulates physiological insulin secretion, but bypasses the liver. Such CSII release can be adjusted according to the specific needs of a patient. Insulin delivery, however, may be interrupted by infusion malfunction, needle displacement, pump dysfunction, and lack of insulin in the reservoir, therefore frequent blood glucose estimation is required. ${ }^{17}$

TABLE. Timeline of insulin development $t^{6-13}$

\begin{tabular}{|c|c|}
\hline Date/year & Development of insulin \\
\hline 11 January 1922 & $\begin{array}{l}\text { The first human administration of beef pancreatic extract at Toronto General Hospital, Toronto, Canada, to a } 14-y e a r-o l d \\
\text { boy with type } 1 \text { diabetes called Leonard Thompson. This experiment, however, was a failure as the insulin caused an } \\
\text { allergic reaction and its efficacy could not be proven. }{ }^{6}\end{array}$ \\
\hline 1922 & JW Collip, a biochemist, purified the pancreatic extract. \\
\hline 1923 & Eli Lilly produced insulin from beef pancreas commercially, ${ }^{7}$ but its potency varied. \\
\hline 1936 & $\begin{array}{l}\text { HC Hagedorn, a chemist in Denmark, prolonged the action of insulin by adding protamine }{ }^{8} \text { and Scott and Fisher }{ }^{9} \text { added } \\
\text { zinc for the same purpose, which led to introduction of once-daily long-acting insulin. }\end{array}$ \\
\hline 1974 & $\begin{array}{l}\text { A newer generation of animal insulin was introduced by eliminating proinsulin and other immunogenic peptide impurities } \\
\text { by using chromatography and charcoal adsorption, thus reducing insulin impurity I from } 1 \% \text { to }<50 \text { ppm. This insulin } \\
\text { was called a monocomponent by Nova and single-peak insulin by Eli Lilly. }{ }^{10} \text { Purification had reduced the incidence of } \\
\text { hypersensitivity reaction and lipoatrophy by insulin. }\end{array}$ \\
\hline 1974 & $\begin{array}{l}\text { Ciba Geigy succeeded in producing human insulin (CGP 12831) by total chemical synthesis, but the process was } \\
\text { expensive. }{ }^{11}\end{array}$ \\
\hline 1976 & $\begin{array}{l}\text { Eli Lilly developed the technique of bioengineering and, in } 1981 \text {, Gentech and Eli Lilly produced the first recombinant } \\
\text { human insulin by inserting a synthetic human insulin gene into Escherichia coli, which translated a code to synthesise } \\
\text { either the A or B protein chain of insulin. The two chains were then combined chemically to form the complete insulin } \\
\text { molecule identical to human insulin, which was marketed in } 1982 .{ }^{12} \text { Novo performed the same bioengineering technique, } \\
\text { using yeast for insulin production. }{ }^{13} \text { These rDNA human insulins are pure and do not cause hypersensitivity reaction, and } \\
\text { bulk production is possible. }\end{array}$ \\
\hline
\end{tabular}




\section{Implantable insulin pump}

An implantable insulin pump is a combination of a continuous glucose sensor attached to a closed-loop insulin infusion pump. The device is also known as an artificial pancreas. Blood glucose control is achieved by using wireless communication of a continuous glucose monitor linked to an insulin infusion pump that facilitates automated data transfer and delivers insulin subcutaneously without the need for human intervention. ${ }^{18}$ The lag period of human insulin given subcutaneously by a pump is 60 to 90 minutes, which can be minimised by using newer fast-acting insulin analogues. Despite important developments in sensor and pump technology, this device has shown delays and inaccuracies in both glucose sensing and insulin delivery, which is a problem when controlling postprandial hyperglycaemia that occurs substantially faster than the time needed for insulin absorption and action. Suboptimal accuracy and reliability remain one of the biggest obstacles for closed-loop systems. Despite the substantial progress made in recent years, there remains a number of challenges to successful development of commercial implantable insulin pump devices. These challenges include the effect of exercise, concurrent illness, large carbohydrate meals, and the pharmacokinetics of current subcutaneous insulin.

Quick-acting insulin has a lag period of 60 to 90 minutes, therefore, it is required to be administered 30 minutes before meals to control postprandial hyperglycaemia and may cause late postprandial hypoglycaemia. To overcome this problem, rapidacting insulin analogues such as aspart, lispro, and glulisine were synthesised by modifying amino acid sequences in the insulin chain so as to keep insulin in a monomeric form, which has a rapid onset of action of 10 to 15 minutes, peak of 30 to 90 minutes, and duration of 3 to 4 hours resembling physiological postprandial insulin secretion. Thus, these analogues are very efficient at controlling postprandial hyperglycaemia without the risk of delayed hypoglycaemia. ${ }^{19}$ Research has been done to enhance the onset of action of human insulin by combining it with human hyaluronidase. ${ }^{20}$

One approach to creating ultrarapid-acting insulin is use of a novel combination of excipients to modify the insulin hexamer complex resulting in more rapid dissociation of the hexamers into monomers and dimers following subcutaneous injection. Biodel Inc (Danbury [CT], US) has developed a technology that facilitates more rapid absorption of recombinant human insulin than that of current insulin products. Biodel is developing Linjeta (previously known as VIAject), an ultrarapid-acting, injectable recombinant human insulin formulation, which is currently under review by the US Food and Drug Administration (FDA) to compare its pharmacokinetic and pharmacodynamic characteristics with rapidly acting insulin analogues. ${ }^{21}$ BIOD-531 (Biodel Inc) has a more rapid onset and longer duration of action than combined prandial/basal insulins. The preclinical and clinical data demonstrate its unique and attractive pharmacokinetic and pharmacodynamic profiles. ${ }^{22}$ This formulation of recombinant human insulin has the potential to provide improved glucose control compared with insulin products designed to provide both prandial and basal coverage in a single injection. As BIOD-531 is a concentrated formulation (400 units $/ \mathrm{mL}$ ), the degree of glucose control can be achieved with a small volume of injection.

Long-acting insulin analogues were designed to obtain a steady basal insulin level compared with older intermediate-acting insulin, which has a risk of late-night hypoglycaemia. Insulin glargine and insulin detemir were designed by altering amino acid sequences in the human insulin chain to make a slow-release preparation when administered subcutaneously. Insulin degludec is another long-acting insulin approved by the US FDA in 2012 for basal blood sugar control. All these long-acting peakless insulins are given once a day to control basal blood sugar level without risk of producing hypoglycaemia. ${ }^{23}$ PEGylated insulin lispro (LY2605541) is a long-acting insulin whereby the insulin molecule is embedded in a polyethylene glycol (PEG) chain to increase the molecular size of the insulin, thus reducing its rate of absorption. ${ }^{24}$ LY2605541 has completed phase 2 clinical trials.

\section{Newer trends in needle-free insulin delivery systems}

None of the above formulations delivered insulin by needle-free technique, thus there is a continuing search for a novel insulin delivery to overcome the problem of needle prick. The newer trends for a needle-free insulin delivery system are discussed as follows.

\section{Insulin inhaler}

Owing to the large surface area, the lung is an ideal target for drug delivery, and inhaled insulin represents one of the most promising alternatives to injectable insulin. Insulin has been developed in powdered form. Exubera (Pfizer Inc, New York [NY], US) was the first inhalable insulin utilising recombinant human insulin. Exubera was approved by US FDA in 2006 for both type 1 and type 2 diabetics. As the inhaler contains shortacting insulin, it can only control postprandial hyperglycaemia. The powdered form of insulin can sometimes stick together making it difficult to inhale and reducing accuracy of the dose. A drawback of Exubera was that it was a bulky inhaler device and insulin was available in a blister packet that had to 
be loaded into the inhaler device for each dose. ${ }^{25}$ Since insulin is known to have growth-promoting properties by acting on insulin-like growth factor receptors, clinicians have been concerned about the possibility of long-term effects of intra-alveolar deposition of insulin, although safety data collected by Pfizer did not show any significant increase in the incidence of lung malignancy in clinical trials. ${ }^{26}$ A systematic review showed that Exubera was not superior to short-acting insulin in other formats and was not cost-effective, so Pfizer discontinued production. ${ }^{27}$ MannKind Corporation (Valencia [CA], US) received US FDA approval in June 2014 for its ultrarapid-acting inhalation human insulin powder, Afrezza, which contains recombinant human insulin using the technosphere concept and is administered via MannKind's next-generation inhaler called Dreamboat. Technosphere technology is based on the $\mathrm{pH}$-induced intermolecular selfassembly of a novel small-molecule excipient (fumaryl diketopiperazine). The technosphere drug delivery system creates insulin microparticles (2-3 $\mu \mathrm{m})$, which form microspheres that are lyophilised into dry powder for inhalation, and dissolve immediately once they come in contact with alveoli. The peak plasma concentration is achieved at 12 to 15 minutes, ${ }^{28}$ resembling physiological postprandial insulin release, and thus it is required to be administered just before meals, and controls postprandial hyperglycaemia only. Afrezza was approved by the US FDA for both type 1 and type 2 diabetes, with a label restriction for patients with asthma, chronic obstructive pulmonary disease, or lung cancer.

\section{Mouth spray and adhesives}

The buccal route is another promising alternative for insulin delivery as this area has an abundant blood supply, thus offering the possibility of delivery of acid-labile insulin without undergoing first-pass metabolism. Spray insulin preparations deliver insulin in aerosol form, which is absorbed through the inside of the cheek and the back of the mouth. Generex Biotechnology Corporation (Toronto, Canada) developed the buccal insulin formulation Oral-lyn, which is a liquid formulation of regular human insulin with a spray propellant using rapid mist technology. Oral-lyn has an onset time of 5 minutes, with a peak of 30 minutes and duration of 2 hours, and can be used to control postprandial hyperglycaemia, having only $10 \%$ drug absorption. ${ }^{29}$ This formulation releases large micelles with a particle size of $>10 \mu \mathrm{m}$, so insulin does not reach the lungs. The US FDA approved Oral-lyn for type 1 and type 2 diabetes in 2009.

MidaSol Therapeutics (Oxford, UK), a joint venture between nanotechnology firm Midatech Pharma (Abingdon, UK) and drug delivery specialist
MonoSol Rx (Warren [NJ], US), has cleared its first clinical hurdle in its bid to develop a gold-based nanoparticle formulation of insulin that offers a novel delivery route. A phase 1 trial of MidaForm insulin, which is administered in a soluble strip that adheres to the inside of the mouth, demonstrated good safety and tolerability. The strip creates an osmotic gradient across the buccal mucosa resulting in rapid systemic delivery of insulin, with a peak plasma concentration time of 5 to 8 minutes. ${ }^{30}$

\section{Transdermal insulin}

Transdermal insulin delivery could provide diabetic patients with a sustained physiological level of basal insulin in a pain-free manner. Dermal permeation is limited to small lipophilic molecules, as the stratum corneum is the major barrier to penetration. Several physical enhancement techniques such as iontophoresis, ultrasound, microneedles, electroporation, lesser ablation, and chemical enhancement have been explored to increase the permeability of transdermal drugs. ${ }^{31}$ The U-Strip (Ultrasonic Strip) Insulin Patch (Transdermal Specialties, Inc, Broomall [PA], US) was designed to deliver insulin lispro through the dermis using alternating sonic waveforms to enlarge the diameter of skin pores, enabling large-diameter molecules to penetrate the stratum corneum. ${ }^{32}$ The U-Strip is at an advanced stage of clinical trial, but is not yet approved by the US FDA.

\section{Oral insulin}

The oral route of administration is considered to be most acceptable and convenient for treatment of chronic diseases. The concept of oral insulin delivery has always been a challenge as the insulin has to be protected from the acidic environment of stomach and various metabolising enzymes, and has poor permeability due to its hydrophilicity. Oral insulin delivery has the advantage that it delivers the drug through the portal circulation, thus distributing a high concentration in the liver resembling physiological insulin secretion. Various attempts have been made to overcome the obstacles of oral insulin therapy. Insulin has been complexed with cyclodextrins in order to improve its solubility and stability in the form of dry powder, after encapsulation into poly(D,L-lactic-co-glycolic acid) microspheres. Other attempts at oral insulin delivery include incorporating insulin with a delivery agent (sodium N-[8-(2-hydroxybenzoyl)amino] caprylate), preparation of hyaluronan-insulin complex and calcium phosphate-PEG-insulin-casein particles for oral delivery. ${ }^{33}$ The physiological barriers to absorption of oral insulin are its low bioavailability and high inter-patient variability.

Biocon Ltd (Bangalore, India) has entered into a research collaboration with Nobex Corporation 
(Research Triangle Park [NC], US) to jointly develop the oral insulin analogue IN-105. The recombinant human insulin molecule has been modified by linking a single short-chain amphiphilic oligomer, through a covalent non-hydrolysable amide bond, to the free amino acid group on the Lys- $\beta 29$ residue. This improved the solubility, stability, and systemic absorption. ${ }^{34}$ From the results published so far, ${ }^{35}$ it appears that IN-105 is a rapid-acting oral insulin that could potentially have a place in the control of postprandial hyperglycaemia. Biocon is collaborating with Bristol-Myers Squibb (New York [NY], US) for global clinical trials. In India, IN-105 has completed a phase 2 clinical trial with promising results. ${ }^{36}$

Oramed Pharmaceuticals (Jerusalem, Israel) was granted patent approval for its oral insulin technology by the Japan Patent Office in April 2013. The POD (Protein Oral Delivery) technology combines adjuvants that are capable of significantly enhancing the absorption of peptides and proteins across the intestinal wall when delivered orally without modifying the active compounds. These adjuvants are intended to protect the active peptide or protein while in transit through the harsh chemical environment of the gastro-intestinal tract and promote its transport across the intestinal wall into the general blood circulation. The tablet is enteric-coated, thus preventing insulin release in the stomach, and the increased $\mathrm{pH}$ of the intestines signals it to open and the technology to start functioning. ${ }^{37}$ The technology is in phase 2 clinical trial, and preliminary data in patients with type 1 and type 2 diabetes are encouraging. ${ }^{38}$

Another oral insulin analogue under development by Novo Nordisk (Bagsværd, Denmark) incorporates Merrion Pharmaceuticals' (Wilmington [NC], US) Gastrointestinal Permeation Enhancement Technology. This technology uses specially designed oral formulations of absorption enhancers that activate micelle formation, facilitating transport of drug and substantially increasing absorption, with good reproducibility. The specially coated tablets are targeted to dissolve in the duodenum releasing both drug and absorption enhancer, which may pass through the duodenal cell membrane. Novo Nordisk has completed a phase 1 study of oral insulin NN1952 as well as another molecule, NNC0148-0000-0362 (NN1954), in healthy participants and patients with type 1 and type 2 diabetes. ${ }^{39}$

There is renewed hope for the treatment of type 1 diabetes with gel capsules. The Norwegian University of Science and Technology has developed a new type of capsule called Trondheim Alginate Microcapsule, which is designed to camouflage the insulin-producing cells from the body's immune system. If this becomes a medical reality, diabetic patients with transplanted insulin-producing donor cells in their abdominal cavity might not have to take immunosuppressants for the rest of their lives. ${ }^{40}$

\section{Pancreas transplantation and stem cell therapy}

Intensified exogenous insulin therapy rarely attains normal blood glucose levels without risk of major hypoglycaemic episodes, and cannot approximate normal physiological pulsatile insulin secretary patterns with complete integrity. Pancreas transplantation is the only therapy shown to stop the progression of diabetic complications without increasing the incidence of hypoglycaemic events. Whole pancreas transplantation was first performed for treatment of diabetes in $1966 .{ }^{41}$ While percutaneous islet cell transplantation is a minimally invasive cellular replacement therapy that was developed to avoid the surgical complications of whole pancreas transplantation, ${ }^{42}$ both procedures require immunosuppressant therapy.

Developments in this fast-moving area of research have focused on the principle of generating insulin-expressing cells from stem cells, with the possibility of generating unlimited numbers of functional beta cells for transplantation therapy. The adoption of a stem cell-based therapy for diabetes, however, will depend on it being shown to be as safe and effective as the current therapy of administration of exogenous insulin.

The stem cell populations that have been used in experimental studies can be tissue stem cells, defined as multipotent progenitor cells found in fetal and adult tissues; embryonic stem cells, defined as pluripotent, undifferentiated cells generated from the inner cell mass of a developing blastocyst; or induced pluripotent stem cells, defined as pluripotent cells generated by reprogramming differentiated adult cells by forced expression of pluripotency genes. The pluripotency and proliferative potential of stem cell populations raises the undesirable possibility of uncontrolled cellular proliferation and formation of teratomas after transplantation, which has been reported in animal studies. ${ }^{43}$ Autologous grafting of insulin-secreting cells derived from the patient's own tissue stem cells is attractive, but experimental studies have not yet translated into clinically useful material, mainly because of problems with restricted proliferative capacity, causing low levels of insulin. Thus, in spite of the impressive promise of stem cells, no proven benefits have been demonstrated by stem cell therapy in the treatment of diabetes.

$$
\text { Xenotransplantation refers to the }
$$

transplantation of tissue or organs from one species to another. This therapy offers the ability to overcome the problem of transplant organ shortage. At present, pigs are thought to be the best candidates for xenotransplant donation, as they are plentiful, quick to mature, and breed well. Transplantation of porcine islet cells into non-human primates has been 
successfully performed with encouraging results, including longer graft survival, ${ }^{44}$ but the benefits of xenotransplantation must be weighed against the potential for interspecies transmission of viral infection and issues related to incongruity of tissue ageing between humans and swine.

\section{Conclusion}

Insulin has saved the lives of countless people since its discovery as a pancreatic crude extract. The advances made in insulin delivery could surely provide intensive insulin therapy regimens that can reduce the multiple daily subcutaneous injections and heavy burden of compliance on patients. Research and development in insulin delivery technology has opened new avenues that can be explored for the cure and control of insulin-dependent diabetes mellitus. The day does not seem to be far away when the parenteral route of insulin administration, which has been the only suitable route, will be outdated and patients will be using alternative routes with ease and comfort. Alternative technologies for the delivery of insulin will be a major breakthrough in changing the lifestyles of millions of diabetic patients around the globe. Therefore, research and investigation into the development of safer and more effective systems for delivery of insulin must continue.

\section{Declaration}

No conflicts of interests were declared by authors.

\section{References}

1. Unwin N, Whiting D, Gan D, Jacqmain O, Ghyoot G, editors. IDF Diabetes Atlas. 4th ed. Brussels: International Diabetes Federation; 2009.

2. Ramachandran A, Snehalatha C, Shetty AS, Nanditha A. Trends in prevalence of diabetes in Asian countries. World J Diabetes 2012;3:110-7.

3. von Mering J, Minkowski O. Diabetes mellitus nach pankreas extirpation. Arch Exp Pathol Pharmacol 1890;26:371-87.

4. Bliss M. The history of insulin. Diabetes Care 1993;16 Suppl 3:4-7.

5. Banting FG, Best $\mathrm{CH}$. Internal secretion of the pancreas. J Lab Clin Med 1922;7:251-66.

6. Banting FG. The history of insulin. Edinburg Med J 1929;36:1-18.

7. Discovery of insulin: A medical marvel for the sugar sickness. Available from: http://www.trumanlibrary.org/ histday/insulin/eli-lilly-and-company.html. Accessed Mar 2015.

8. Hagedorn HC, Jensen BN, Krarup NB, Wodstrup I. Protamine insulinate. JAMA 1936;106:177-80.

9. Scott DA, Fisher AM. The effect of zinc salts on the action of insulin. J Pharmacol Exp Ther 1935;55:206-21.

10. Deckert T, Andersen OO, Poulsen JE. The clinical significance of highly purified pig-insulin preparations. Diabetologia 1974;10:703-8.

11. Teuscher A. The biological effect of purely synthetic human insulin in patients with diabetes mellitus. Schweiz Med Wochenschr 1979;109:743-7.

12. Keen H, Glynne A, Pickup JC, et al. Human insulin produced by recombinant DNA technology: safety and hypoglycaemic potency in healthy men. Lancet 1980;2:398401.

13. Markussen J, Damgaard U, Pingel M, Snel L, Sørensen AR, Sørensen E. Human insulin (Novo) chemistry and characteristics. Diabetes Care 1983;6 Suppl 1:4-8.

14. Magwire ML. Addressing barriers to insulin therapy: the role of insulin pens. Am J Ther 2011;18:392-402.

15. Logwin S, Conget I, Jansa M, Vidal M, Nicolau C, Gomis R. Human insulin-induced lipoatrophy. Successful treatment using a jet-injection device. Diabetes Care 1996;19:255-6.

16. Blevins T, Schwartz SL, Bode B, et al. A study assessing an injection port for administration of insulin. Diabetes Spectr 2008;21:197-201.

17. Dandona P, Foster M, Healey F, Greenbury E, Beckett AG. Low-dose insulin infusions in diabetic patients with high insulin requirements. Lancet 1978;2:283-5.

18. Peyser T, Dassau E, Breton M, Skyler JS. The artificial pancreas: current status and future prospects in the management of diabetes. Ann N Y Acad Sci 2014;1311:10223

19. Powers AC, D’Alessio D. Endocrine pancreas and pharmacotherapy of diabetes mellitus and hypoglycemia. In: Goodman and Gilman's: The pharmacological basis of therapeutics. 12th ed. New Delhi: McGraw Hill; 2011: $1237-73$

20. Hompesch M, Muchmore DB, Morrow L, Vaughn DE. Accelerated insulin pharmacokinetics and improved postprandial glycemic control in patients with type 1 diabetes after coadministration of prandial insulins with hyaluronidase. Diabetes Care 2011;34:666-8.

21. Steiner S, Hompesch M, Pohl R, et al. A novel insulin formulation with a more rapid onset of action. Diabetologia 2008;51:1602-6.

22. Morrow L, Hompesch M, Canney L, Pichotta P, Krasner A, de Souza E. Biphasic pharmacokinetic and pharmacodynamic profiles associated with concentrated insulin BIOD-531 show rapid onset and basal duration of action. Poster presented at the EASD Annual Meeting 2014; 15-19 September 2014; Vienna, Austria. Abstract \#937.

23. Tahrani AA, Bailey CJ, Barnett AH. Insulin degludec: a new ultra-longacting insulin. Lancet 2012;379:1465-7.

24. Rosenstock J, Bergenstal RM, Blevins TC, et al. Better glycemic control and weight loss with the novel long-acting basal insulin LY2605541 compared with insulin glargine in type 1 diabetes: a randomized, crossover study. Diabetes Care 2013;36:522-8.

25. Barnett AH. Exubera inhaled insulin: a review. Int J Clin Pract 2004;58:394-401.

26. Barnett AH, Lange P, Dreyer M, Serdarevic-Pehar M; Exubera Phase 3 Study Group. Long-term tolerability of inhaled human insulin (Exubera) in patients with poorly controlled type 2 diabetes. Int J Clin Pract 2007;61:161425.

27. Black C, Cummins E, Royle P, Philip S, Waugh N. The clinical effectiveness and cost-effectiveness of inhaled insulin in diabetes mellitus: a systematic review and economic evaluation. Health Technol Assess 2007;11:1126.

28. Rosenstock J, Lorber DL, Gnudi L, et al. Prandial inhaled insulin plus basal insulin glargine versus twice daily biaspart 
insulin for type 2 diabetes: a multicentre randomised trial. Lancet 2010;375:2244-53.

29. Modi P, Mihic M, Lewin A. The evolving role of oral insulin in the treatment of diabetes using a novel RapidMist System. Diabetes Metab Res Rev 2002;18 Suppl 1:S38-42.

30. Soares S, Costa A, Sarmento B. Novel non-invasive methods of insulin delivery. Expert Opin Drug Deliv 2012;9:1539-58

31. Park EJ, Dodds J, Smith NB. Dose comparison of ultrasonic transdermal insulin delivery to subcutaneous insulin injection. Int J Nanomedicine 2008;3:335-41.

32. Insulin patch offers hope of needle free diabetes management. Unveiled at American Diabetes Association's 72nd Annual Scientific Meeting on June 9-11 2012 in Philadelphia. Heritage. Eli Lilly and Company. Available from: http://srxawordonhealth.com/2012/06/01/insulinpatch-offers-hope-of-needle-free-diabetes-management/. Accessed Sep 2015.

33. Semalty A, Semalty M, Singh R, Saraf SK, Saraf S. Properties and formulation of oral drug delivery systems of protein and peptides. Indian J Pharm Sci 2007;69:741-7.

34. Kinesh VP, Neelam DP, Punit BP, Bhavesh SB, Pranga KS. Novel approach for oral delivery of insulin and current status of oral insulin products. Int J Pharm Sci Nanotechnology 2010;3:1057-64.

35. Heinemann L, Jacques Y. Oral insulin and buccal insulin: a critical reappraisal. J Diabetes Sci Technol 2009;3:568-84.

36. Khedkar A, Iyer $\mathrm{H}$, Anand A, et al. A dose range finding study of novel oral insulin (IN-105) under fed conditions in type 2 diabetes mellitus subjects. Diabetes Obes Metab 2010;12:659-64.
37. Kidron M, Arbit E, Shushlav Y. Comparative assessment of the glucose-lowering effect of multiple oral insulin (ORMD-0801) formulation variant in pigs. Paper presented at the 74th Scientific Sessions of the American Diabetes Association; 13-17 June 2014; San Francisco, California, USA.

38. Neutel J, Kidron M, Arbit E, Homer K. Bedtime oral insulin lowers fasting blood glucose levels in T2DM patients. Poster presented at the 74th Scientific Sessions of the American Diabetes Association; 13-17 June 2014; San Francisco, California, USA.

39. A trial investigating the safety, tolerability, pharmacokinetics and pharmacodynamics of NNC0148-0000-0362 in healthy subjects. Available from: https://clinicaltrials.gov/ct2/ show/NCT01597713. Accessed Sep 2015.

40. de Vos P, Lazarjani HA, Poncelet D, Faas MM. Polymers in cell encapsulation from an enveloped cell perspective. Adv Drug Deliv Rev 2014;67-68:15-34.

41. Kelly WD, Lillehei RC, Merkel FK, Idezuki Y, Goetz FC. Allotransplantation of the pancreas and duodenum along with the kidney in diabetic nephropathy. Surgery 1967;61:827-37.

42. Hatipoglu B, Benedetti E, Oberholzer J. Islet transplantation: current status and future directions. Curr Diab Rep 2005;5:311-6.

43. Parnaud G, Bosco D, Berney T, et al. Proliferation of sorted human and rat beta cells. Diabetologia 2008;51:91-100.

44. Hering BJ, Wijkstrom M, Graham ML, et al. Prolonged diabetes reversal after intraportal xenotransplantation of wild-type porcine islets in immunosuppressed nonhuman primates. Nat Med 2006;12:301-3. 